\title{
The emergence of marketing in Millennial new ventures
}

\author{
David Lingelbach, Anthony Patino and Dennis A. Pitta \\ Marketing \& Entrepreneurship, University of Baltimore, Baltimore, Maryland, USA
}

\begin{abstract}
Purpose - The purpose of this paper is to develop a conceptual framework, based in entrepreneurship theory, which explains how marketing emerges in startups founded by members of the Millennial generation.

Design/methodology/approach - Following a literature review, from which propositions are derived, an earlier process model of organizational speciation is adapted to marketing by Millennial entrepreneurs.

Findings - A four-stage cycle model of entrepreneurial marketing by Millennials is developed, consisting of enabling through resource scarcity, bonding through social media, new product introduction through incremental stealth, and replicating through variation, selection, and retention.

Research limitations/implications - Model development would be enhanced through empirical data.

Practical implications - Marketers in entrepreneurial firms founded by Millennials can follow a few simple rules to enhance market penetration. Resource scarcity is something to be sought, not avoided. A thoughtful social media strategy can accelerate new product introduction: stealthiness and its close relation small size should be embraced; avoid getting too big too quickly; use furtiveness to drive social media-based bonding.

Originality/value - Previous theoretical models at the marketing/entrepreneurship interface have not focused on the unique characteristics of Millennial-led new ventures. This study develops the most comprehensive model of entrepreneurial marketing by Millennials to date.
\end{abstract}

Keywords Millennials, Entrepreneurship, Effectuation, Entrepreneurialism, Business formation, Marketing

Paper type Conceptual paper

An executive summary for managers and executive readers can be found at the end of this article.

\section{Introduction}

The interface between marketing and entrepreneurship has been of growing interest to both scholars and practitioners (Hills et al., 1989-2009; Carter, 2006; Hoy, 2008; Kraus et al., 2010; Read et al., 2009). Some researchers have defined the marketing/entrepreneurship interface as the distinct subdiscipline of entrepreneurial marketing (Morris et al., 2002; Hills et al., 2008), while others have pointed to the dominance of entrepreneurial theory in shaping the interface (Hansen and Eggers, 2010). Sidestepping this debate, a set of alternative theories has increasingly challenged textbook marketing techniques, emphasizing service-dominant logic (Vargo and Lusch, 2004) and effectuation (Read et al., 2009). Marketing is central to the creation of new ventures (Hunt, 2002; Gonzalez-Benito et al., 2009; Read et al., 2009), particularly during the opportunity recognition or creation stage of the entrepreneurial process.

Simultaneously with the refinements in marketing theory, the sociological literature has explored the characteristics of generational cohorts (Abramson and Inglehart, 1995). The Millennial generation is also described variously as individuals who have never experienced a world without personal computers, the internet, and toys with major features (like

The current issue and full text archive of this journal is available at www.emeraldinsight.com/0736-3761.htm

Journal of Consumer Marketing

29/2 (2012) 136-145

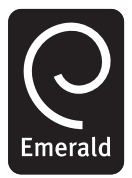

Limited [ISSN 0736-3761]

[DOI 10.1108/07363761211206384] computer games, or devices like the Gameboy). More pertinently, the sociological literature describes the Millennial generation's between-group differences with older cohorts in detail. While the within-group differences among Millennials may be equally important, their overall pattern of preferences is argued to have important implications on their work ethic and attitudes. In fact, the earlier academic writings on Millennials portrayed them as less willing to devote themselves to their jobs, preferring a balanced work/family life (Myers and Sadaghiani, 2010). They were also described as more willing to work for others and less willing to invest in entrepreneurial pursuits.

In reality the picture is not that simple. In any generational population, subsets exist which are willing to work for their own ends, taking risks in the hope of reaping rewards. Indeed, propensity to risk is arguably the defining characteristic of entrepreneurship. Supporting the view of differences in generational subsets is the observation that the current global economic slump is propelling increasing numbers of Millennials into entrepreneurship since external employment opportunities are less available (Ribitzky, 2011).

Despite these varied and growing literatures developing an alternative marketing construct and describing Millennials, little attention has been paid to the question of how new ventures founded by the emerging generation of Millennial entrepreneurs - those born between 1982 and 2000 - market their products. Consequently a generalizable theoretical model of the marketing/entrepreneurship interface - one that can remain valid as Millennial entrepreneurs become more and more important - has remained elusive. One emerging construct, based on the effectuation construct (Sarasvathy, 2001), argues that entrepreneurial expertise embodied in individuals who have founded and remained with one or more startups through ten years, IPO, and $\$ 200$ million in annual revenues - leads to a fundamentally 
different approach to marketing than that found in managers in established firms (Read et al., 2009). In comparison to managers, expert entrepreneurs rely less on market research, draw more on prior experience, focus to a greater degree on affordable losses, think more holistically about the business, are more likely to identify or create new markets, pursue price skimming strategies, and, in the distribution channels, rely more on direct marketing, co-creation with distribution partners, and focus on narrow segments (Read et al., 2009). While conceptually appealing, the effectuation construct in marketing does not account for new ventures founded by Millennials, which are unlikely to possess much expertise, given the relative youth of the founders. Examples of successful millennial-founded new ventures - Facebook, Groupon, and WordPress - and core Millennial traits specialness, sheltered, confident, team-oriented, conventional, pressured, and achieving (Strauss and Howe, 1991) - suggest that the relationship between entrepreneurial expertise and marketing may be more complex than suggested in the effectuation-based model.

\section{Millennials and the marketing/entrepreneurship interface}

The Millennial generation provides a rich and distinctive domain in which to explore this interface and begin to elaborate a conceptual framework of the marketing/ entrepreneurship interface. Entrepreneurship is a significant activity amongst Millennials (Fenn, 2010; Kirkpatrick, 2010; Mezrich, 2009; Reiser, 2010). Millennial entrepreneurs include Mark Zuckerberg, Dustin Moskovitz, and Eduardo Saverin (Facebook), Andrew Mason (Groupon), Suhas Gopinath (Bangalore-based Globals, Inc) and William Kamkwamba (electricity-generating windmills in Malawi made from junk). Notably, Millennial entrepreneurs are distinctive from earlier generations along six dimensions:

1 blending social and commercial purposes;

2 aligning private, public, and NGO resources;

3 leveraging communities and collaboration;

4 adapting to millennial environments;

5 embracing knowledge globalization;

6 and solving systemic problems while meeting market needs (Salkowitz, 2010).

The vast majority of today's 4.2 billion Millennials live in developing and emerging economies (Salkowitz, 2010), offering a global dataset from which a comprehensive theoretical framework could be derived. Many of these entrepreneurs may market to the "bottom of the pyramid," where optimal marketing strategies remain under development (Pitta et al., 2008; Sridharan and Viswanathan, 2008). These "Third World" Millennial entrepreneurs often rely on information and communications technology(ICT)enabled business models (Salkowitz, 2010), allowing researchers to isolate industry effects in developing a framework. By focusing on Millennial entrepreneurs, such a framework complements other work that has focused on Millennials as consumers, students, or citizens.

The purpose of this paper is to elaborate a conceptual framework that better articulates how Millennial entrepreneurs market their products. We integrate emerging insights from entrepreneurship theory, including effectuation, resource-advantage, coproduction, and diffusion, with generational analysis, emphasizing the distinctive features of the Millennial generation that shed light on a fuller understanding of the marketing/entrepreneurship interface.

The paper proceeds as follows. After briefly describing our method, we conduct a literature review, from which a series of propositions are developed. These propositions are then organized into a rudimentary model that can guide future research.

\section{Method}

We review the literature of three research streams: the marketing/entrepreneurship interface, generational analysis, and the emergence of new organizational forms. Based on this review, we propose a conceptual framework to guide future research.

\section{The marketing/entrepreneurship interface and Millennials: what do we know?}

\section{The marketing/entrepreneurship interface}

The interface between marketing and entrepreneurship has called attention to the unique characteristics of new ventures that limit the relevance of traditional marketing theories. In general, new ventures are distinctive in comparison to more established firms along four dimensions: newness, smallness, uncertainty and turbulence (Gruber, 2004). These dimensions suggest the outlines for an alternative approach to marketing incorporating these dimensions.

A startup's newness can create a lack of trust with potential customers and may also introduce entry barriers to established or emerging markets through a new venture's lack of pre-existing relationships with prospective customers. New ventures are also less likely to have both established marketing processes and significant marketing experience. A new venture's small size limits the marketing budget and often demands high levels of marketing effectiveness, given that limited budget. Small size may also limit access to critical marketing skills. The uncertainty and turbulence faced by many new ventures - particularly those introducing new products or entering markets in the process of formation limits the usefulness of existing market data, requires new ventures to keep their strategic options open, and limits the visibility of marketing best practices or even the likely dominant design in a new product domain. In addition, unlike established firms, entrepreneurial firms face all of these challenges nearly simultaneously. Consequently, extant marketing theory is of limited relevance to marketers in entrepreneurial firms (Gruber, 2004).

New ventures respond to these marketing challenges in a variety of ways. One approach - entrepreneurial marketing has been defined as "a proactive, innovative, risk-taking approach to the identification and exploitation of opportunities for attracting and retaining profitable customers" and "an alternative approach to marketing" under conditions of "change, complexity, chaos, and contradiction" (Morris et al., 2002, pp. 1, 5). It involves a variety of marketing tactics with guerilla (Levinson, 1998), expeditionary (Hamel and Prahalad, 1992), environmental management (Zeithaml and Zeithaml, 1984), radical (Hill and Rifkin, 1999), subversive (Bonoma, 1986), and proactive (Davis et al., 1991) elements (Morris et al., 2002). 
Taking uncertainty as the central attribute of entrepreneurial settings, another approach - based on effectuation - argues that expert entrepreneurs reject the predictive methods associated with traditional marketing theory in favor of a marketing process that inverts predictive rationality and argues that "to the extent that people can control the future, they do not need to predict it" (Read et al., 2009 , p. 2). An effectual approach to marketing contains the following elements: skepticism about market research; analogical reasoning based on prior experience; focus on existing financial resources, marketing costs, and what the startup can afford to lose; explicit visualization of the whole business while making marketing decisions; flexibility in considering more alternative markets, even at the cost of product or strategy change; higher pricing to capitalize on value identified in specific customers; and focused channel strategies around partnerships to serve narrow customer groups (Read et al., 2009). Each of these elements is fundamentally different than those followed by traditional marketing managers.

These findings are echoed in a recent study that has sought to distinguish the different types of entrepreneurial action. The marketing mix varies depending on the basis for entrepreneurial action undertaken (Alvarez and Barney, 2007). Two contexts for entrepreneurial action have been suggested: discovery and creation (Alvarez and Barney, 2007). Discovery-based (Kirznerian) entrepreneurship is a process consisting of defined stages around opportunity identification and exploitation, resource acquisition, strategy, and organizing (Shane, 2003). On the other hand, entrepreneurial action centered on opportunity creation (Schumpeterian) is characterized by a fundamentally different set of effective actions reflecting the inherently uncertain (as opposed to risky) nature of opportunities in this context. In the creation context, marketing reflects the changes in the marketing mix that emerge from new opportunities (Alvarez and Barney, 2007). This is fundamentally different than marketing in the discovery context, where "changes in the marketing mix may be how new opportunities manifest themselves" (Alvarez and Barney, 2007 , p. 17). The creation context of entrepreneurship is similar to that described by Read et al. (2009).

Effectuation-based approaches to marketing emphasize the importance of entrepreneurial expertise. This expertise is based on experience gained over at least ten years. The age range of the expert entrepreneur sample on which the findings of Read et al. (2009) are based is between 40 and 82 years. How, then, might the findings of this study be applied to a population of Millennial entrepreneurs, the oldest of which is 29 years? We consider this question next by examining generational analysis and the attributes of Millennial entrepreneurs.

\section{Generational analysis and Millennial entrepreneurs}

The concept of "Millennials" was first articulated in a popular study of American history and is based on a cyclical theory of history (Strauss and Howe, 1991). Cyclical theories assert that phases recur in the same order and are of similar duration. The cyclical theory developed in Strauss and Howe (1991, 1997; Howe and Strauss, 2000) asserts that four generational archetypes have been identified in AngloAmerican history and have analogous peers in other countries. These archetypes are identified as prophet, nomad, hero, and artist (Strauss and Howe, 1997). Each generation belongs to one of these archetypes. Millennials are a part of the hero archetype, members of which are characterized as intuitive thinkers notable for their founding tendencies (Strauss and Howe, 1997). Although Walt Disney is not a member of the Millennial generation, he is a member of the hero archetype notable for his reinvention of the entertainment industry through the animation medium (Gabler, 2006). Millennial entrepreneurs have been similarly noteworthy for their creation of new industries such as social media (Facebook) and the reinvention of existing industries such as retailing (Groupon) and software (WordPress). Millennials and Millennial entrepreneurs possess unique characteristics, which shape the approach that their new ventures take to marketing.

While initial studies of Millennials have focused on the US context, most Millennial entrepreneurs are located in developing and emerging economies (Salkowitz, 2010). These institutional environments have been characterized as limited access orders, in which dominant local elites maintain social order in part by restricting innovation in order to preserve their economic rents (North et al., 2009). New venture creation in these economies is generally restricted to un-innovative firms that do not directly compete with businesses owned or controlled by elites. Unlike their counterparts in developed economies with open access orders characterized by political and economic competition, Millennials in developing and emerging countries are constrained as a result by resource scarcity which shapes how they respond to opportunities to enter new markets or introduce new products.

When working with the Millennial construct, rigorous generational analysis is necessary. Generational identity can be understood through three approaches:

1 cohort;

2 age; and

3 incumbency-based approaches (Joshi et al., 2010).

Of these, the age-based approach - in which early adulthood memories are shaped by historic events - underpins the generational analysis on which the Millennial concept is based. Age-based generational identity is based on common earlier experiences of novel historical events, creating collective memories (Schuman and Scott, 1989). While empirical data on early adulthood Millennial memories of critical events does not yet exist, the Millennial early adulthood period began in 2000, when the first Millennials turned 18. We can infer that historical events that have occurred since 2000 - 9/11, the Iraq invasion, Katrina, and the 2008 financial crisis - are likely to have shaped Millennial generational identity.

The relative importance of age-, cohort-, and incumbencybased generational identities varies by organizational context, with technology-oriented firms such as Microsoft and Google emphasizing incumbency-based identities in which resources are exchanged between past, present, and future incumbents (Joshi et al., 2010). Thus, it seems reasonable to assume that the technology-oriented firms favored by Millennial entrepreneurs are likely to deemphasize the age-based identity on which the Millennial moniker is based and, instead, to emphasize flat organizations with strong knowledge flows across functional silos. 
Effectuation describes a logic of entrepreneurial expertise based on non-predictive control. In contrast to causal models of managerial expertise based on a logic of prediction leading to control, effectuation argues that expert entrepreneurs start by assessing their means, determining what they can afford to lose, and then building their new ventures in collaboration with potential partners, including initial customers, suppliers, and investors. Effectuation logic is depicted in Figure 1.

\section{Millennials and effectuation based marketing}

While few Millennial entrepreneurs are likely to possess significant entrepreneurial expertise on which an effectuationbased marketing approach could be built, we argue that the intense historical events faced by them in early adulthood have created a strong age-based generational identity. This identity's strength has created an almost tribal bonding amongst members of the Millennial generation. These bonds and their manifestation through intensive usage of interpersonal communication and social media - for example texting and Facebook - have provided Millennial entrepreneurs with unusual insights into the habits and preferences of their generation's members. Millennials possess key psychographic traits, including a high need for relationships and communication (Rainer and Rainer, 2011). This expertise may substitute to some extent for the longer gestation periods of entrepreneurial expertise associated with earlier generations, such as those studied in Read et al. (2009).

We next consider how marketing emerges in the context of new ventures established by Millennials.

\section{Effectuation and the emergence of new organizational forms}

The marketing model suggested in Read et al. (2009) is based on a more general model of the effectual process, developed in Sarasvathy and Dew (2005) (see Figure 1). The principles on which the effectual process is based have important implications for the development of a marketing model for Millennial entrepreneurs, as suggested in Table I.

Table I suggests that marketing by Millennial entrepreneurs benefits from resource scarcity, bonding with stakeholders, and flexibility in implementing marketing. We now explore the implications of these conclusions for a possible model of Millennial entrepreneur marketing.

Resource scarcity is a foundational characteristic of many Millennial new ventures. In order to create appropriate enabling conditions for new product marketing, we argue that resource scarcity must be present. Resource scarcity has been a fundamental condition of new venture creation in all settings (Sahlman, 1990). However, in developing and emerging economies (the principal institutional setting for Millennial entrepreneurs), high levels of growth, poverty, and uncertainty, as well as low levels of innovation, have led to competitive advantage through the development of alternative business models such as frugal production and reverse innovation (The Economist, 2010). While the resourcebased view has suggested that an abundance of specialized resources is required for entrepreneurial activity (George, 2005), a more recent research stream has argued that, in some settings, organizational development can be assisted by resource scarcity (Gassmann and Keupp, 2007; Katila and Shane, 2005; Sapienza et al., 2006). In this narrative, organizations stretch outside of existing borders in order to

Figure 1 The effectual process

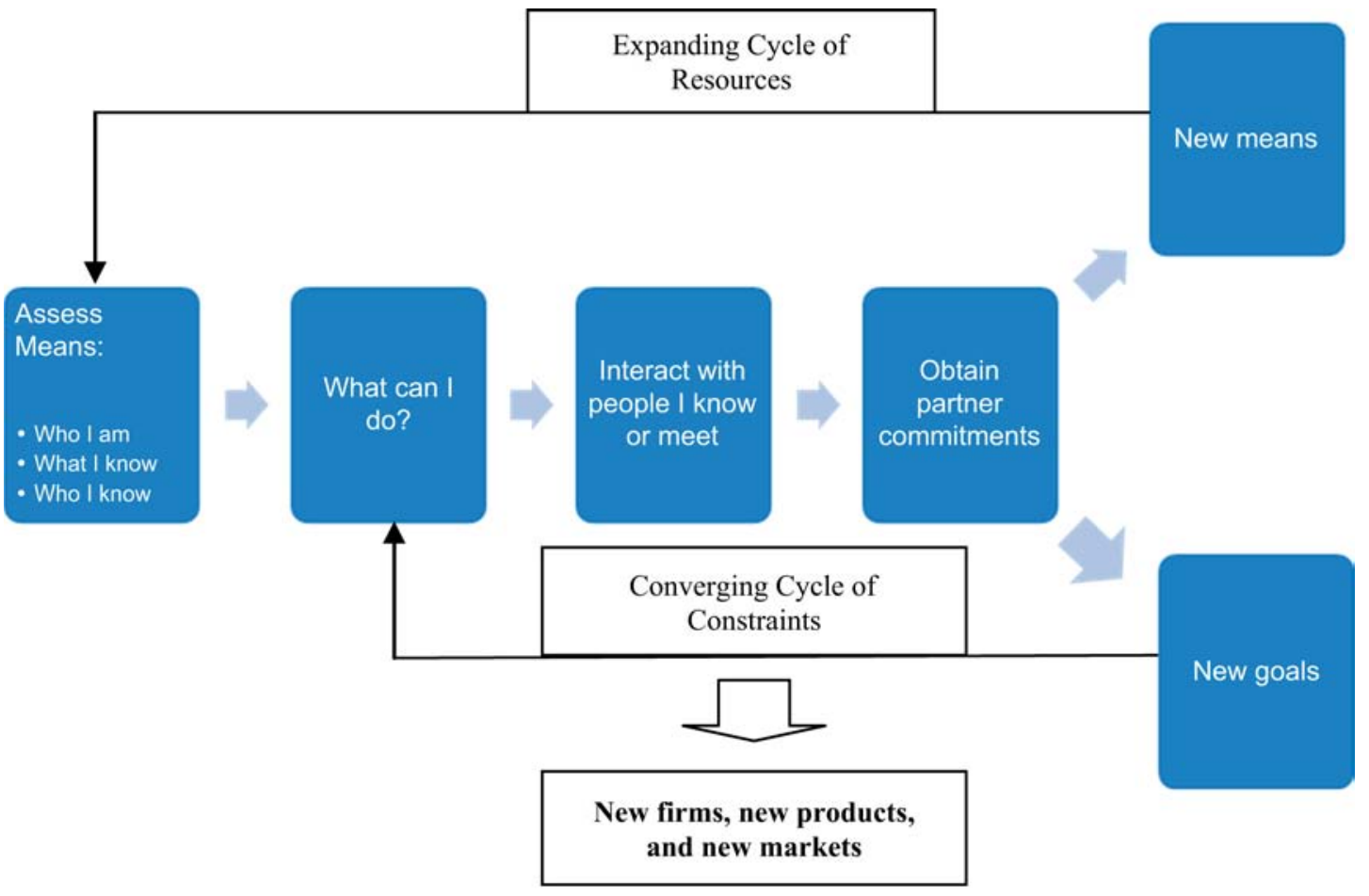

Sources: Based on Sarasvathy and Dew (2005); Read et al. (2009) 
Table I The impact of effectual thinking on marketing by Millennial entrepreneurs

\begin{tabular}{|c|c|c|}
\hline Issue & Effectual approach & Impact on Millennial entrepreneur marketing \\
\hline View of the future & Creative & Product co-creation with stakeholders (customers, suppliers, investors) \\
\hline Basis for taking action & Means oriented & Resource scarcity (by firm and customers) drives product design and marketing \\
\hline View of risk and resources & Affordable loss & $\begin{array}{l}\text { Resource scarcity limits financial investment in new products and marketing to } \\
\text { that which stakeholders can afford to lose }\end{array}$ \\
\hline Attitude toward outsiders & Partnerships & Sharing with committed stakeholders that have complementary assets \\
\hline $\begin{array}{l}\text { Attitude toward unexpected } \\
\text { events }\end{array}$ & Leverage & $\begin{array}{l}\text { Maintain flexibility (keep options open by limiting investment in existing } \\
\text { operations) to shift marketing in response to surprises }\end{array}$ \\
\hline
\end{tabular}

Source: Read et al. (2009)

access resources and opportunities (Mathews and Zander, 2007), converting scarcity to an advantage.

Resource scarcity may be a source of competitive advantage for certain types of activities, and following the recent financial crisis organizations have operated under conditions of scarcity for long periods. Despite this scarcity, these firms have introduced both incremental and radical innovations. As relatively young and inexperienced business owners, Millennial entrepreneurs are more likely to have difficulties in acquiring resources required for business launch, new product development, and effective marketing.

Entrepreneurial marketers leverage scarce resources through two broad strategies: "letting others pay" and "big bang for the buck" (Gruber, 2004). Free-riding (including targeting established markets and mimicry) and forming alliances are two sub-strategies that allow others to pay for a new venture's marketing efforts. Niche, guerrilla, and "step by step" approaches help to get the greatest return on a small marketing investment. Of these, guerrilla marketing has attracted the greatest practitioner interest, but remains conceptually vague. Elements of guerrilla marketing can include word of mouth, fan clubs, free samples, PR, and viral marketing (Gruber, 2004). More generally, resource leveraging is accomplished using the following strategies (Morris et al., 2002):

- Stretching resources.

- Utilizing resources that others have found useless.

- Using others' resources to accomplish the new venture's purposes (free-riding).

- Complementing one resource with another.

- Using one resource to obtain another.

Therefore, we suggest that:

P1. Millennial entrepreneurs rely on enabling conditions of resource scarcity in order to launch new products.

We argue that, once resource scarcity has stimulated a new product launch by a Millennial entrepreneur, effective marketing becomes possible through bonding with key stakeholders, including early adopting customers. Expert entrepreneurs co-create the future with stakeholders who precommit to new ventures and their products (Read et al., 2009). They also share their new products with partners who have complementary assets that can contribute to the product's successful launch. Millennial entrepreneurs and their stakeholders create social capital in the process. Social capital refers to "the information, trust, and norms of reciprocity inhering in one's social networks" (Woolcock, 1998).
Millennial entrepreneurs are more likely to use social media-based marketing techniques, such as viral marketing, to bond with early adopters. Millennials seek relationships and are committed to developing mentorship relationships (Rainer and Rainer, 2011). In some instances, entrepreneurial marketing becomes an exercise in open innovation, in which Millennial entrepreneurs and early adopters co-design cutting edge product offerings.

Therefore, we argue that:

P2. Bonding between Millennial entrepreneurs and potential stakeholders is central to launching new products and is facilitated by social media.

Given that many products developed by Millennial entrepreneurs are radical innovations that may challenge the economic rents of industry incumbents, we argue that new product launch following bonding and possible co-design with early adopters must proceed by "incremental stealth" (Lingelbach et al., 2011). In this process new products are introduced in bits and snatches, almost furtively, so as to avoid attention from any incumbents or substitutes.

When Millennial entrepreneurs are unable to form partnerships with potential stakeholders, such as dominant elites, an "incremental stealth" approach becomes especially important to new product introduction. Imperceptible and piecemeal introduction of new product elements over time avoids direct competition with existing products marketed by elite firms with greater market (and political) power (Lingelbach et al., 2011).

The emergence of venture capital (VC) in developing and emerging economies is an example of the "incremental stealth" process. Weak and atomized actors in these institutional settings import elements of VC practice, while taking advantage of the accidental import of other practice elements, all in a manner that goes unnoticed by dominant elites and those firms whose rents might be competed away by the emergence of a new competitor. Over time institutional entrepreneurs gradually assemble these elements into a new practice, resulting in the emergence of innovative managerial practice (Lingelbach et al., 2011).

We propose that:

P3. New production introduction by Millennial new ventures is facilitated by incremental stealth.

Finally, once the Millennial entrepreneur has launched a new product, that new product must be accepted in the wider marketplace through a replication process. This process consists of continuous variation in product design (including 
modification), selection of one product design by the market, and retention of that superior product.

P4. Once a Millennial new venture's product has been launched, it is replicated in the marketplace through a variation, selection, and retention mechanism.

While the "normal" entrepreneurial marketing process described in this model consists of the sequence resource scarcity $\rightarrow$ social media $\rightarrow$ incremental stealth $\rightarrow$ replicating, it is possible to commence this marketing process at any one of the processes in the cycle. For example, an impatient Millennial entrepreneur, unwilling to wait for attractive enabling conditions, may begin marketing her product by bonding with stakeholders, then introducing the product by incremental stealth, and replicating new product acceptance. Only then might enabling conditions become sufficiently attractive to draw other Millennial entrepreneurs into the market. The process could also commence with stealthy new product introduction, leading to new product acceptance, and only later create sufficient enabling conditions and bonding with key stakeholders.

Moreover, a feedback effect exists between new product introduction via incremental stealth and bonding with key stakeholders through social media. Gradual and furtive new product introduction may strengthen bonding with early adopters.

Therefore:

P5. In the Millennial new venture's marketing process, four stages - enabling, bonding, diffusing, and replicating - are linked cyclically, with feedback between the bonding and diffusing processes.

An earlier model of organization speciation asserted that new organizational forms emerge through a four stage cyclical model consisting of enabling, bonding, diffusing, and replicating stages (Lingelbach et al., 2011; Lingelbach, 2011) (Figure 2).

This model can be adapted to explain how Millennial entrepreneurs market new products (see Figure 3).

The case of Facebook illustrates how Millennial entrepreneurs market their new products. Mark Zuckerberg contended with resource scarcity at the firm's inception.

Figure 2 A model of organizational speciation

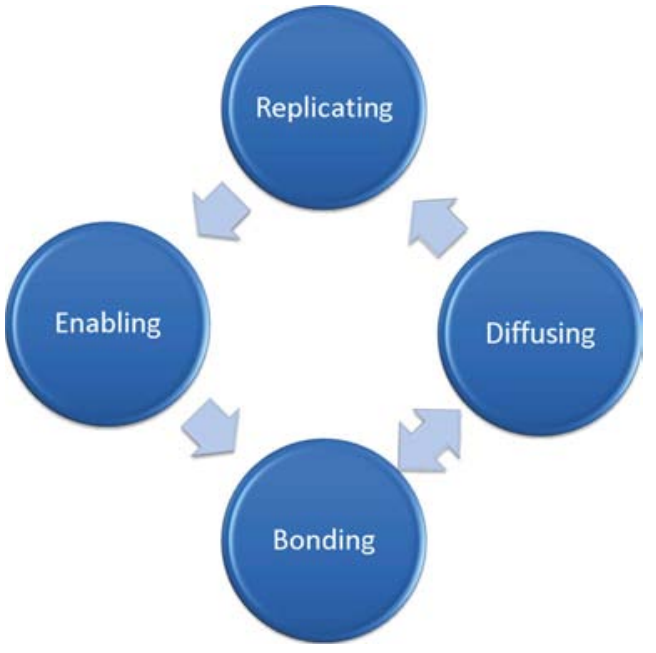

Figure $3 \mathrm{~A}$ model of Millennial entrepreneurial marketing emergence

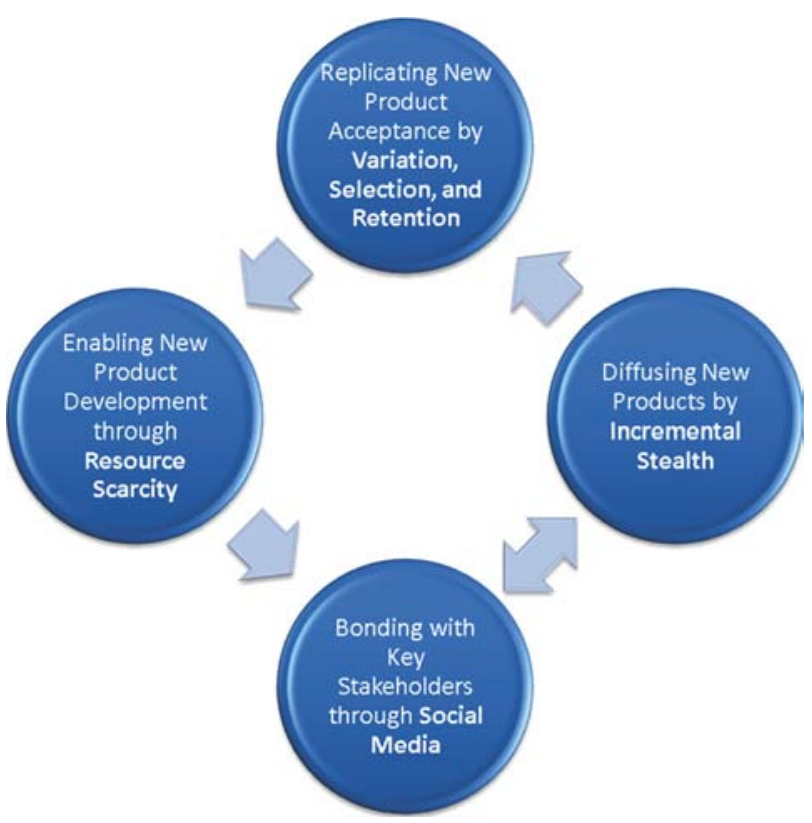

However, rather than being held back by this constraint, Zuckerberg managed this scarcity by hacking into Harvard's computer network to copy photographs of Harvard students (Kirkpatrick, 2010). While this action violated Harvard's policy, it represents one measure of entrepreneurial creativity in overcoming scarcity. As the firm continued to develop, bonding with key stakeholders took place in two ways. First, the network effect - in which value is created by each new member of Facebook - co-created value for Zuckerberg and Facebook's members. Second, Zuckerberg shared notes for a Harvard art history course with Facebook members, demonstrating social studying as a bonding process that cocreates value (Mezrich, 2009). Akin to recipes provided to consumers by manufacturers of cooking ingredients, this technique helped build sales and acceptance. Incremental stealth as a mechanism to facilitate new product introduction was central to Facebook's growth. Zuckerberg hid Facebook's development from the Winklevoss brothers, with whom he had agreed to develop a separate, but similar, product (Mezrich, 2009). Finally, once the basic Facebook product was launched to the Harvard community, it was replicated to other college campuses, and then varied to accommodate new markets among high schoolers, Microsoft and Apple employees, and, eventually, the general public (Mezrich, 2009). Table II maps Facebook's marketing into traditional marketing categories.

\section{Results}

We combine insights from effectuation theory (Read et al., 2009), generational analysis, and a stage theory of organizational speciation (Lingelbach et al., 2011) to create a conceptual model for marketing by Millennial entrepreneurs. This model is cyclical and consists of four stages: enabling through resource scarcity, bonding through social media, new product introduction through "incremental stealth", and replicating through variation, selection, and retention. 
Table II Optimal marketing mix for Millennial entrepreneurs

\begin{tabular}{|c|c|c|}
\hline Category & Optimal Choice & Rationale \\
\hline Product & Connections & Social media \\
\hline Price & Free & Resource scarcity \\
\hline Distribution channel & ICT, e.g. internet, mobile device & Incremental stealth \\
\hline Promotion strategy & Word of mouth & Incremental stealth \\
\hline Customer service strategy & Self service & Resource scarcity \\
\hline
\end{tabular}

Study of entrepreneurship among the Millenials may provide insight into broader organizational phenomenon beyond this particular cohort or behavior.

\section{Marketing implications}

The model of Millennial entrepreneurial marketing elaborated here has a number of important implications for Millennial entrepreneurs and those who wish to market to them. Since the focus has been on how Millennial entrepreneurs market, other markers may find it helpful to adopt the approach. Marketers should find it helpful to understand the approach to exploit possibilities for cooperation and partnership.

Alternatively, knowing how Millennials market and communicate may serve as valuable intelligence about potential adversaries. Larger firms which understand the Millennial approach might profit in being vigilant against strategic challenges that originate from unexpected directions, namely "off the grid."

Several of the elements explored above are pertinent to the Millennial entrepreneur. While resource scarcity can be viewed as a constraint that will hamper success, it may actually be a goad to propel Millennial entrepreneurs toward effective solutions that leverage other factors such as relationship building with stakeholders or finding breakthrough technological advances. In addition, resource scarcity may foster a creative problem solving approach that avoids the potential trap of following the traditional pathway. Thus, resource scarcity is something to be sought, not avoided.

Social media including online consumer communities have proliferated and matured with the Internet age. They represent a paradigm shift in promotion and market research. In the past, marketers, and brand managers used traditional media, at a cost, to reach consumers to convince them to buy products and services. Today, the entrepreneur may choose to partner with existing consumer groups, Gossieaux and Moran's tribes, who are available online and are already marketing to themselves. Moreover, Millennial entrepreneurs and social media are almost by definition connected. The Millennial generation is so internet savvy and experienced in maintaining connections with their peers, and online communities that using social media effectively is second nature. Thus, a thoughtful social media strategy can accelerate new product introduction.

Stealthiness and its close relation, small size, should be embraced. Traditionally, smaller firms are viewed as more flexible with a lower financial footprint compared to larger firms, which are advantages. While smaller size may translate into vulnerability to larger competitors, small size may also enhance stealthiness. Millennial entrepreneurs may be able to use furtiveness to drive social media-based bonding. One lesson is to avoid getting too big too quickly.

The last element in the model, replication (through variation, selection, and retention) may be typical of any new product introduction that succeeds and needs to be maintained. The Millennials, both entrepreneurs and consumers, will know how to communicate their needs and ideas, easing further new product creation.

These findings have several weaknesses. Controversy continues as to the validity of the Millennial construct and generational analysis. Some researchers have identified Millennials as selfless (Howe and Strauss, 2000), while others see them as either narcissistic (Twenge, 2007) or ignorant and alliterate (Bauerlein, 2009). Critics have argued that "generational images are stereotypes" (Levine in Hoover, 2009) and suggested that "generational thinking is just a benign form of bigotry, in which you flatten out diversity" (Vaidhyanathan in Hoover, 2009).

It is also unclear if the Millennial concept is based on a shared generational identity that will persist over time, or is simply a reflection of the youthfulness of current Millennials, the characteristics of which will fade as they age. Entrepreneurship research has identified age as an important non-psychological individual difference that contributes to the decision to exploit opportunities (Shane, 2003). These studies do not separate cohort and age effects, are not longitudinal, and therefore may not be generalizable to later generational cohorts such as the Millennials.

\section{References}

Abramson, P.R. and Inglehart, R. (1995), Value Change in Global Perspective, University of Michigan, Ann Arbor, MI.

Alvarez, S.A. and Barney, J.B. (2007), "Discovery and creation: alternative theories of entrepreneurial action", Strategic Entrepreneurship fournal, Vol. 1 No. 1, pp. 11-26.

Bauerlein, M. (2009), The Dumbest Generation: How the Digital Age Stupefies Young Americans and Feopardizes our Future (Or, Don't Trust Anyone under 30), Tarcher, New York, NY.

Bonoma, T.V. (1986), "Marketing subversives", Harvard Business Review, Vol. 64 Nos 11/12, pp. 113-8.

Carter, M. (2006), "Entrepreneurship and marketing", in Casson, M., Yeung, B., Basu, A. and Wadeson, N. (Eds), The Oxford Handbook of Entrepreneurship, Oxford, New York, NY, pp. 114-37.

Davis, D., Morris, M. and Allen, J. (1991), "Perceived environmental turbulence and its effect on selected entrepreneurship, marketing and organizational characteristics in industrial firms", Fournal of Academy of Marketing Science, Vol. 19 No. 1, pp. 43-51. 
(The) Economist (2010), "A special report on innovation in emerging markets", The Economist, pp. 1-15, April 15.

Fenn, D. (2010), Upstarts!: How GenY Entrepreneurs are Rocking the World of Business and 8 Ways You Can Profit from their Success, McGraw-Hill, New York, NY.

Gabler, N. (2006), Walt Disney: The Triumph of the American Imagination, Vintage, New York, NY.

Gassmann, O. and Keupp, M.M. (2007), "The competitive advantage of early and rapidly internationalizing SMEs in the biotechnology industry: a knowledge-based view", Fournal of World Business, Vol. 42 No. 3, pp. 350-66.

George, G. (2005), "Slack resources and the performance of privately held firms", Academy of Management fournal, Vol. 48 No. 4, pp. 661-76.

Gonzalez-Benito, O., Gonzalez-Benito, J. and MunozGallego, P.A. (2009), "Role of entrepreneurship and market orientation in firms' success", European fournal of Marketing, Vol. 43 Nos 3/4, pp. 500-22.

Gruber, M. (2004), "Marketing in new ventures: theory and empirical evidence", Schmalenbach Business Review, Vol. 56 No. 2, pp. 164-99.

Hamel, G. and Prahalad, C.K. (1992), "Corporate imagination and expeditionary marketing", Harvard Business Review, Vol. 69 No. 4, pp. 31-43.

Hansen, D.J. and Eggers, F. (2010), "The marketing/ entrepreneurship interface: a report on the 'Charleston Summit", Fournal of Research in Marketing and Entrepreneurship, Vol. 12 No. 1, pp. 42-53.

Hill, S. and Rifkin, G. (1999), Radical Marketing: From Harvard to Harley, Lessons from Ten that Broke the Rules and Made It Big, Harper Collins, New York, NY.

Hills, G.E. et al. (Eds) (1989-2009), Research at the Marketing/ Entrepreneurship Interface, Vols. 2-22, University of Chicago, Chicago, IL.

Hills, G.E., Hultman, C.M. and Miles, M.P. (2008), "The evolution and development of entrepreneurial marketing", Fournal of Small Business Management, Vol. 46 No. 1, pp. 99-112.

Hoover, E. (2009), "The millennial muddle: how stereotyping students became a thriving industry and a bundle of contradictions", The Chronicle of Higher Education, October 11.

Howe, N. and Strauss, N. (2000), Millennials Rising: The Next Great Generation, Vintage, New York, NY.

Hoy, F. (2008), "Organizational learning at the marketing/ entrepreneurship interface", fournal of Small Business Management, Vol. 46 No. 1, pp. 152-8.

Hunt, S.D. (2002), Foundations of Marketing Theory: Toward A General Theory of Marketing, M.E. Sharpe, Armonk, NY.

Joshi, A., Dencker, J.C., Franz, G. and Martocchio, J.J. (2010), "Unpacking generational identities in organizations", Academy of Management Review, Vol. 35 No. 3, pp. 392-414.

Katila, R. and Shane, S. (2005), "When does lack of resources make new firms innovative?", Academy of Management Fournal, Vol. 48 No. 5, pp. 814-29.

Kirkpatrick, D. (2010), The Facebook Effect: The Inside Story of the Company that Is Connecting the World, Simon \& Schuster, New York, NY.

Kraus, S., Harms, R. and Fink, M. (2010), "Entrepreneurial marketing: moving beyond marketing in new ventures", International fournal of Entrepreneurship and Innovation Management, Vol. 11 No. 1, pp. 19-34.
Levinson, C. (1998), Guerrilla Marketing: Secrets for Making Big Profits from Your Small Business, Houghton Mifflin, Boston, MA.

Lingelbach, D. (2011), "Paradise postponed? Venture capital emergence in a transition economy", paper presented at 12th Annual International Conference, Higher School of Economics, Moscow, April 5-7.

Lingelbach, D., Gilbert, E. and Murray, G. (2011), “'Incremental stealth': practice diffusion in limited access orders", (forthcoming).

Mathews, J.A. and Zander, I. (2007), "The international entrepreneurial dynamics of accelerated internationalization", fournal of International Business Studies, Vol. 38, pp. 387-403.

Mezrich, B. (2009), The Accidental Billionaires: The Founding of Facebook's Tale of Sex, Money, Genius and Betrayal, Doubleday, New York, NY.

Morris, M.H., Schindehutte, M. and LaForge, R.W. (2002), "Entrepreneurial marketing: a construct for integrating emerging entrepreneurship and marketing perspectives", fournal of Marketing Theory and Practice, Vol. 10 No. 4, pp. 1-19.

Myers, K. and Sadaghiani, K. (2010), "Millennials in the workplace: a communication perspective on Millennials' organizational relationships and performance", fournal of Business $\mathcal{E}$ Psychology, Vol. 25 No. 2, pp. 225-38.

North, D.C., Wallis, J.J. and Weingast, B.R. (2009), Violence and Social Orders: A Conceptual Framework for Interpreting Recorded Human History, Cambridge University Press, New York, NY.

Pitta, D.A., Gueslaga, R. and Marshall, P. (2008), “The quest for the fortune at the bottom of the pyramid: potential and challenges", fournal of Consumer Marketing, Vol. 25 No. 7, pp. 393-401.

Rainer, T.S. and Rainer, J.W. (2011), The Millennials: Connecting to America's Largest Generation, B\&H, Nashville, TN.

Read, S., Dew, N., Sarasvathy, S.D., Song, M. and Wiltbank, R. (2009), "Marketing under uncertainty: the logic of an effectual approach", fournal of Marketing, Vol. 73 No. 5, pp. 1-18.

Reiser, R. (2010), Millennials on Board: The Impact of the Rising Generation on the Workplace, Intern Bridge, Acton, MA.

Ribitzky, R. (2011), "Young jobs in the balance", Porfolio.com, February 9, available at: www.portfolio.com/ views/blogs/entrepreneurship/2011/02/09/millennials-tur ning-to-entrepreneurship-and-sidepreneurship-to-combatjob-climate/ (accessed March 30, 2011).

Sahlman, W.A. (1990), "The structure and governance of venture-capital organizations", fournal of Financial Economics, Vol. 27 No. 2, pp. 473-521.

Salkowitz, R. (2010), Young World Rising: How Youth, Technology and Entrepreneurship Are Changing the World from the Bottom up, Wiley, New York, NY.

Sapienza, H.J., Autio, E., George, G. and Zahra, S.A. (2006), "A capabilities perspective on the effects of early internationalization on firm survival and growth", Academy of Management Review, Vol. 31 No. 4, pp. 914-33.

Sarasvathy, S.D. (2001), "Causation and effectuation: toward a theoretical shift from economic inevitability to entrepreneurial contingency", Academy of Management Review, Vol. 26 No. 2, pp. 243-63. 
Sarasvathy, S.D. and Dew, N. (2005), "New market creation as transformation", fournal of Evolutionary Economics, Vol. 15 No. 5, pp. 533-65.

Schuman, H. and Scott, J. (1989), "Generations and collective memories", American Sociological Review, Vol. 54, pp. 359-81.

Shane, S. (2003), A General Theory of Entrepreneurship: The Individual-Opportunity Nexus, Edward Elgar, Cheltenham.

Sridharan, S. and Viswanathan, M. (2008), "Marketing in subsistence marketplaces: consumption and entrepreneurship in a south Indian context", fournal of Consumer Marketing, Vol. 25 No. 7, pp. 455-62.

Strauss, W. and Howe, N. (1991), Generations: The History of America's Future, 1584-2069, William Morrow, New York, NY.

Strauss, W. and Howe, N. (1997), The Fourth Turning: An American Prophecy, Broadway, New York, NY.

Twenge, J.M. (2007), Generation Me: Why Today's Young Americans Are More Confident, Assertive, Entitled - and More Miserable Than Ever Before, Free Press, New York, NY.

Vargo, S. and Lusch, R. (2004), "Evolving to a new dominant logic for marketing”, fournal of Marketing, Vol. 68 No. 1, pp. 1-17.

Woolcock, M. (1998), "Social capital and economic development: toward a theoretical synthesis and policy framework", Theory and Society, Vol. 27 No. 2, pp. 151-208.

Zeithaml, C. and Zeithaml, V. (1984), "Environmental management: revising the marketing perspective", fournal of Marketing, Vol. 48 No. 2, pp. 46-53.

\section{About the authors}

Dr David Lingelbach is an Assistant Professor in the Department of Marketing and Entrepreneurship at the University of Baltimore. David Lingelbach is the corresponding author and can be contacted at: dlingelbach@ubalt.edu

Dr Anthony Patino is an Assistant Professor in the Department of Marketing and Entrepreneurship at the University of Baltimore.

Dr Dennis A. Pitta is a Professor in the Department of Marketing and Entrepreneurship at the University of Baltimore

\section{Executive summary and implications for managers and executives}

This summary has been provided to allow managers and executives a rapid appreciation of the content of this article. Those with a particular interest in the topic covered may then read the article in toto to take advantage of the more comprehensive description of the research undertaken and its results to get the full benefits of the material present.

An increasing number of researchers are examining the relationship between entrepreneurialism and marketing. Some studies are conducted with regard to identifying distinctive traits and tendencies of specific generational cohorts. Particular attention is being paid to Millennials, described as technologically astute, confident, team oriented and conventional. Members of this cohort also consider themselves special and have a strong desire for success.
These macro traits impact on attitudes and behaviors, although it is important to recognize the existence of subgroups within the cohort. For instance, employment opportunities are scarcer in the current economic climate and this has seen more Millennials prepared to take the risk and become entrepreneurs.

Despite this knowledge, how these entrepreneurs market products offered by their new ventures remains largely uninvestigated. Previous studies have found that entrepreneurs differ from managers of recognized companies in their approach to marketing. Direct marketing and the creation of new markets are important to entrepreneurs, who consider their business more holistically, focus on smaller market segments and co-create with distribution partners. They additionally tend to cut prices, concentrate more on affordable losses and depend on prior experience rather than market research. Since this research involved entrepreneurs with a decade of involvement, the findings might not apply to Millennials, because their age makes the same degree of expertise unlikely.

That entrepreneurship is common within this generational cohort is apparent from the success of ventures like Facebook, Groupon and WordPress. Scholars claim that Millennial entrepreneurs differ from earlier generations because they integrate social and commercial goals, align private, public and NGO resources, engage in collaborative ventures, adapt to Millennium environments, adopt a globalized view of knowledge and simultaneously resolve systemic issues and serve market demands.

Traditional marketing is less relevant to new ventures because of their:

- Newness. No pre-existing relationships make trust an issue. A lack of established marketing processes and marketing experience represent other likely barriers;

- Small size. Market budget will typically be limited, increasing the need for marketing efficiency. Yet vital marketing skills might not be available; and

- Uncertainty and turbulence. This heightens when new firms introduce new products or enter new markets at the outset. Current market data will be of limited use and identification of marketing best practices improbable. Taking this approach also demands flexibility towards strategic options.

To compound the difficulty, these challenges emerge almost simultaneously for new ventures. Some respond proactively with a radical approach that aims to seek and exploit opportunities to secure and retain customers. Changing and complex conditions, which trigger chaos and contradiction determine a marketing strategy which contains tactics that also have such as guerilla, expeditionary and dissident elements among others. Additional characteristics include a flexibility to consider alternative markets and an aim to control rather than anticipate the future.

Certain scholars have divided entrepreneurship into discovery and creation. Identifying and exploiting opportunities is at the core of the discovery form, which also focuses on strategy, organization and the acquisition of resources. With action entrepreneurialism, opportunities are created because of the "inherent uncertainty" that surrounds them. In the discovery context, marketing emphasizes the opportunities that arise through marketing mix changes. The 
reverse effect occurs in the creative form because new opportunities cause theses changes.

One theory purports a view that each generational cohort is identified with one of four archetypes that emerge episodically. Millennials are ascribed with the "hero" archetype and this explains their tendency towards intuitive thinking and talent for founding new industries, social media being a prime example.

Studies of Millennials have largely focused on the United States, despite most entrepreneurs of this generation being based in developing and emerging nations. Evidence suggests these entrepreneurs are typically restricted to prevent them competing against firms controlled by those dominating the social order. Resource scarcity is a common obstacle faced.

Age, cohort and incumbency-based approaches are usually employed for research into generation identity. A focus on age posits that major historic events shape early adult memories which subsequently create "collective tendencies", behaviors and preferences. It is also argued that organizational context determines the relevant importance of the approaches. Incumbency-based identities are important where resources are exchanged between past, present and future incumbents. From this it is natural to assume that this approach will be favored over age-based identity in "technologically-oriented firms" created by Millennial entrepreneurs.

However, Lingelbach et al. believe that the impact of historical events creates an age-based identity among Millennials that almost produces "tribal-bonding". This is reinforced by interpersonal connection and social media that also provides insight into what generation members do and prefer.

An effectuation approach to marketing is seen as appropriate since many Millennial entrepreneurs have to begin by evaluating their means. Core elements of this strategy are:

- Resource scarcity. The rationale here is that, rather than serving as an impediment, scarcity enables a more innovative approach to leveraging resources. Options include using resources considered ineffective, adopting those owned by partners or other organizations and making resources stretch further;

- Bonding with key stakeholders such as early adopting customers. A common strategy here is to partner with those possessing complementary assets that can help product launch succeed. Bonding with stakeholders and increasing trust using social networks is important;

- Incremental stealth. Given the scope of radical innovations to challenge industry incumbents or dominant elites, this approach is often necessary to minimize attention from such competitors. Piecemeal introduction is also wise when partnerships with potential stakeholders cannot be created; and

- Replication to generate marketplace acceptance. This involves ongoing design modification and eventual selection of the superior version of the product.

Although these stages of entrepreneurial marketing are cyclical, the authors claim that the process can be started at any of the four stages depending on the favorability of conditions. The creation of Facebook by Mark Zuckerberg is used to illustrate how each stage of this approach is used.

Lingelbach et al. believe that knowledge of how Millennial entrepreneurs operate raises awareness about possible rivals. For larger companies, this can result in better positioning to anticipate challenges from unexpected sources. It is also suggested that resource scarcity should be welcomed as it might facilitate relationship building with stakeholders and inspire greater creativity. Entrepreneurs are encouraged to exploit social media by partnering consumer groups that already boast an online presence. In the authors' opinion, new product introduction can be enhanced by utilizing connections established via social media.

Being small can become an advantage as such operators are invariably more flexible than larger rivals. Smallness is also equated with stealth by Lingelbach et al. The focus on communication by Millennials enables better identification of ideas and needs, which helps ensure new products are relevant.

The argument that generational identity relies on stereotyping possibly limits study claims, as do disagreements about Millennial characteristics. It is also unclear whether Millennials share an identity that will prevail throughout their lifetime or simply an indication of the 'youthfulness' that current members of the cohort exhibit.

(A précis of the article "The emergence of marketing in Millennial new ventures”. Supplied by Marketing Consultants for Emerald.) 
Reproduced with permission of the copyright owner. Further reproduction prohibited without permission. 